UNITED STATES

DEPARTMENT OF THE INTERIOR

GEOLOGICAL SURVEY

AN INTRODUCTION TO THE GEOLOGIC LITERATURE

OF ALASKA

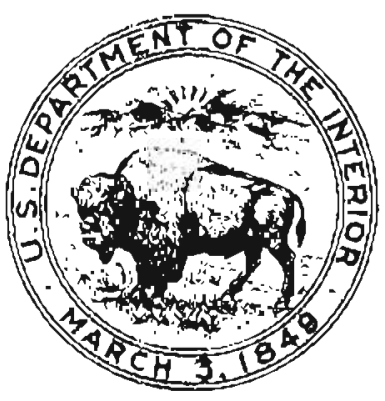

OPEN.FILE REPORT 7E-235

This report is proliminary and has not been edited or reviewed for conformity with Goological Survey standards and nomenclature

Menlo Park. Califormia March 1976 
UNITED STATES

DEPARTMENT OF THE INTERIOR

GEOLOGICAL SURVEY

AN INTRODUCTION TO THE GEOLOGIC LITERATURE

\author{
OF ALASKA
}

By

Donald Grybeck

OPEN-FILE REPORT 76-235

This report is preliminary and has not been edited or reviewed for conformity with Geological Survey standards and nomenclature 


\section{AN INTRODUCTION TO THE GEOLOGIC LITERATURE \\ OF ALASKA}

By

Donald Grybeck

\section{Introduction}

The purpose of this report is to auggest some basic references on the geology of Alasks. In recent years, interest in Alaska and Its resources has increased greatly and much of thls interest is tied directly or Indirectly to the geology of the state. The knowledge of Alaskan geology has accumulated to the polnt where a single publication covering the state in detall would be overpoweringly. large.

The sum of Alaskan geologic Information is lncreasing rapidly and it is likely that this trend wil continue if not accelerate. New geologic data and newly discovered mineral depostts are being reported aloost continuously and new, sometimes atartling, interpretations of Alaskan geology are belng made in rapid succeselon. As an indication of this trend, more than $80 \%$ of the non-serial publications clted here have been published within the last tev years and $60 \%$ within the last flve years. The reader is warned that this report will almost certainly become out of date in the near future and that there 18 no substitute for a continulng awareness of the new Alaskan literature if one is to be fully informed. 


\section{"Ceology of Alaska"}

A number of attempts to synthesize the geology of Alaska have been attempted of varylng length, viewpoints, and timeliness. These include:

Brooks, A. H., and Abbe, Cleveland, Jr., 1906, The geography and geology of Alaska: U.S. Geo1, Survey Prof. Paper 45, 327 p.

Cobb, E. H., 1974, Synopsts of the mineral resources and geology of Alaska: U.S. Geol. Survey Bu11.1307, 53 P.

Smith, P. S., 1939, Areal geology of Alaska: U.S. Geol. Survey Prof. Paper 192, 100 p.

Williams, Kowe11 (ed.), 1958, Landscapes of Alaska: Univ. of Calif. Press, Berkeley, 133 p.

Gates, G. 0., and Gryc, George, 1963, Structure and tectonic history of Alaska in ChIlds, O. E., and Beebe, B. W. (eds.), The backbone of the Americas, a symposium: Amer. Assoc. of Petroleum Geologists Mem. 2, p. 264-277.

U.S. Geological Survey, 1964, Mineral and water resources of Alaska: Committee on Interior and Insular Affalrs, U.S. Senate, $179 \mathrm{p}$.

Unfortunately, there is no receat comprehensive publication on the geology of Alaska.

\section{Geologic Map of Alaska}

A new geologic map of Alaska is now in preparation and part of $1 t$ has been published in a preliminary (uncolored) form.

Beikman, H. M., 1974, Preliminary geolog1c map of the southwest quadrant of Alaska: U.S. Geol. Survey Misc. Fleld Studles Map MF-611, 2 sheets, scale 1:1,000,000.

Belkman, H. M., 1975. Prellminary geologic map of the southeast quadrant of Alaska: U.S. Geol. Survey Misc. Field Studies Map $M F-612,2$ sheets, scale $1: 1,000,000$.

Belkman, H. M., 1975, Prelimtnary geologlc map of southeastern Alaska: U.S. Geol. Survey Misc. Fleld Studles Map MF-673, 2 sheets, scale $1: 1,000,000$. 
Beikman, H, M., 1975, Preliminary geologic map of the Alaska Penfosula and Aleutian Islands: U.S. Geol. Survey Misc. Field Studtes Map, Mp-674, 2 sheets, scale $1: 1,000,000$.

The following may serve for many purposes:

Dutro, J. T., and Payne, T. G., 1957, Geologic map of Alaska: U.S. Geol. Survey, 1 sheet, scale $1: 2,500,000$.

K1ng, P. B., 1969, Tectonfc map of North America: U.S. Geol. Survey, 2 sheets, scale $1: 5,000,000$.

Kfing, P. B., 1969, The tectontcs of North America - a discussion to accorquany the Tectonic Map of North Amerlca, scale 1:5,000,000: U.S. Geo1. Survey Prof. Paper 628, 94 p.

Benulson, A. P., 1974, Geologic inghway map of the State of Alaska and the State of Hawal1: Amer. Assoc. Petroleum Geologists Map 8, 1 shect, scale, 1:3,500,000.

\section{Geological and Geographical Boundaries}

Only Infrequently are political gubdivisions used in referring to geological areas in Alaska. The boundarles may be Imposed by the geology but one of the common subdivisions of the state 1 s by the name of the 153, topographic quadrangles (scale $1: 250,000)$ of the state. Indices to these maps are shown in many references but the primary source 18 the U.S. Geologlcal Survey topographic map Index for Alaska. It outlines the boundartes of the $1: 250,000$-scale maps, 1:63,360-scale maps and the avaliablitty of smaller scale base maps and the date of publication. The most recent index, which is updated periodically, is:

U.S. Geological Survey, 1974, Index to topographic maps of Alaska: v.S. Geo1. Survey, I sheet, scale 1:2,500,000.

Areas may also be referred to by mining or recording district terminology. This ueeage has a long history in Alaska and has been codifted by the U.S. Bureau of Mines: 
Ransome, A. L., and Kerns, W. H., 1954, Names and definitlons of reglons, distrlcts, and subdlstricts, In Alaska: U.S. Bureau of Mines Information Circ. 7679, $91 \mathrm{p}$.

Although not of direct applicdifon to geology, the Alaska Statehood Act of 1958 and the Native Clalms Settlement Act of 1971 have produced major changes in the ownershlp of the land in Alaska - changes which are still in progress. These changes direct much of the geologic work in the state. The U.S. Bureau of Land Management acts as the custodian of the Eederal lands in Alaska and is the Instrument for transferring Eederal land to State, native, and private hands. They maintain land offices in Fairbanks and Anchorage where detalls of land ownersh1p are easily accessible. As well, they publish a map that indicates the land ownership patterns in Alaska:

U.S. Bureau of Land Management, 1974, Alaska: U.S. Bureau of Land Management, 1 sheet, scale 1:2,500,000. (Note, however, that this map is more than a year old and is outdated in many areas.)

The Mapmakers, P. 0. Box 145, Anchorage, Alaska, 99510 have recently published an updated land status map of Alaska which is current as of November $11,1975$.

An exhaustive (and often entertaining) compliation of the location and derfvation of ali features labeled on copographic maps of the U.S. Geological Survey in Alaska has been assembled by Orth:

Orth, D. J., 1967, Dictionary of Alaska place names: U.S. Geol. Survey Prof. Paper 567, 1084 P.

\section{Geologic Map Index}

The outlines of U.S. Geological Survey geologlc mappings in Alaska 18 shown on the following: 
Cobb, E. H., and Kennedy, D. L, , 1967, Geologic map Index of Alaska; 5th ed.: U.S. Geol. Survey, 25 p.

More recently, Cobb has tabulated all U.S. Geological Survey mapping by quadrangle:

Cobb, E. H., 1974, Geologícal Survey published maps (other than ropographic maps) of Alaska indexed by quadrangle: U.S. Geol. Survey open-file report $74-84,38 \mathrm{p}$.

There is no map or compllation which shows all geologic mapping from all souxces for the state. Note, however, that there are sumbarles which are discusged subsequently of all the licerature of Alaskan geology (whych includes most maps) indexed by quadrangles, large reglons, and the state as a whole.

\section{Reglonal and Topical Sumaries}

The following list represents a selection of publications that either discuss the geology of large areas of Alaska or cover topical aspects of Alaskan geology. The material clted is hardly exhaustive and individuals may wish to include other publications, but these in particular have proved belpful in discussing the geology of Alaska:

Adkınson, W. L., and Brosgé, M. M. (eds.), 1970, Preceedings of geological seminar on the North Slope of Alaska: Pacific Sec., Amer-Assoc. of Petroleum Geologists.

Barnes, D. F., 1976, Bouguer gravity map of Alaska: U.S. Geol. Survey open-file report 76-70, 1 sheet, scale 1:2,500,000.

Brew, D. A., Loney, R. A., and Muffler, L. J., 1966, Tectonic history of southeastern Alaska in Gunning, H. C., (ed.), Tectonic hiscory and mineral depostes of western Cordilleras: Canadian Inst. of Mining and Metallurgy, p. 149-170.

ChurkIn, Michael, Jr., 1970, Paleozolc and Precambrian rocks of Alasks and their role in its structural evolution: U.S. Geol. Survey Prof. Paper 740,64 p. 
Douglas, R. J. W: (ed.), 1970, Geology and economic minerals of Canada, 5th ed.: Canada Geol. Survey Econ. Geol. Report 1, 838 p.

Perrlans, O. J., Jr., 1965, Permafrost map of Alaska: D.S, Geol. Survey Misc. Geol. Inv. Map I-445, 1 sheet, scale 1:2,500.000.

Grantz, Arthur, 1966, Strike-s1ip faults In Alaska: U.S. Geol. Survey open-file report, $82 \mathrm{p}$.

Grantz, Arthur, and Krtschner, C. R., 1975, Tectonic framework of petroliferous rocks in Alaska: U.S. Geol. Survey open-file report $75-149,26 \mathrm{p}$.

Imlay, R. W., and Detreman, R. L., 1973, Jurassic paleobiogeography of Alaska: U.S. Geol. Survey Prof. Paper 80l, $34 \mathrm{p}$.

Johnson, P. R., and Harman, C. W., 1969, Evironmental atlas of Alaske: Inst, of Water Resources, Univ. of Alaska, 11 p.

Karlatrom, T. N. V., and other6, 1964, Surflcial geology of Alaska: U.S. Geol. Survey Misc. Geol. Inv. Map I-357, 2 sheets, scale $1: 1,584,000$.

MacNell, F. S., Wolfe, J. A., Miller, D. J., and Hopkins, D. M., 1961, Coorelation of Tertlary formations of Alaska: Amer. Assoc. Petroleum Geologists Bull. v. 45, p. 1801-1809.

Miller, D. J., Payne, T. G., and Gryc, George, 1959, Geology of posstble petroleum provinces in Alaska: U.S. Geol. Survey Bull. $1094,131 \mathrm{p}$.

Patton, W. W., Jr., 1973, Reconnaissance geology of the northern Yukon-Koyukuk provínce, Alaska: U.S. Geol. Survey Prof. Paper 774-A, p. Al-A17.

Pewwe, T. L., 1975, Quaternary geology of Alaska: U.S. Geol. Survey Prof. Paper 835, 145 p.

Rlchards, H. G., 1974, Tectonlc evolution of Alaska: Amer. Assoc. of Petroleum Geologists Bull. v. 58, p. 79-105.

Wahrhaftig, Clyde, 1965, Physlographic divistons of Alaska: U.S. Geo1. Survey Prof. Paper 482, 52 p.

U.S. Geological Survey, 1970, The national atlas of the Untted States of Amertica: U.S. Geol. Survey, $417 \mathrm{p}$.

Zlegler, P. A., 1969. The development of sedimentary basing in wescern and arctic Canada: Alberta Soc, of Petroleum Geologists, $89 \mathrm{p}$. 
In the past few years, a number of publications have atrempted to describe the total natural and man-made enyironment of the state, Including tts cllmatology, geology, hydrology, sotls, biology, and the effects of the human activity:

Jolnt Federal State Land Use Planntng Commtssion for Alaska, 1974, Resources of Alaska, a regional summary: $619 \mathrm{p}$.

Selkregg, L. L. (ed.), 1974, Alaska regional proflles, Southcentral Region: Arctlc Environmental Information and Data Center, Univ. of Alaska, $255 \mathrm{p}$.

Selkregg, L. L. (ed.), 1975, Alaska regional profiles, Arctic Region: Arctlc Environmental Information and Data Center, Univ. of Alaska, $218 \mathrm{p}$.

\section{Blbliographles of Alaskan Geology}

The primary bibliographic source for Alaskan geology ts the Bibllography and Index of Geology and its predecessor:

U.S. Geological Survey, 1923-1967, Bibliography of North American Geology: U.S. Geol. Survey Bull., 746-747 (1785-1918), 823 $(1919-1928), 937(1929-1939), 1049(1940-1949), 1195$ (19501959), $1196(1960), 1197$ (1961), 1232 (1962), 1233 (1963), 1234 (1964), 1235 (1965), $1236(1966), 1267$ (1967), 1268 (1968), $1269(1969), 1370(1970)$.

Geological Soctety of America, 1969- , Bibliography and index of geology: Ceol. Soc. of America, v. 33-.

However, the very completeness and bulk of these bibllographies make them cumbersome. The Alaska Division of Geologlcal and Geophysical Survey has publisbed a serles of bibllographles that selects al1 the Alaskan material from the preceeding bibllographies.

Fritts, C. E., and Brown, M. E., 1971, B1bllography of Alaskian geology 1831-1918: Alaska Div. of Geol. Survey, 88 p.

Frftts, C. E., and Brown, M. E., 1971, Btbliography of Alaskan geology 1919-1949: Alaska Div. of Geol. Survey, 92 p. 
Fritts, C. E., and Brown, M. E, 1971, Bibliography of Alaskan geology 1950-1959: Alaska Div, of Geol. Survey, 83 P.

Fritts, C. E., and Bruwn, M. E., 1971, Blbllography of Alaskan geology 1960-1964: Slaska D1v. of Geol. Survey, 81 p.

Fritts, C. E., and Tuel1, E. J., 1972, Blbliography of Alaskan geology 1965-1968: Alaska Div. of Geol. Survey, 112 p.

Fritts, C. E., and others, 1972, Bibliography of Alaskan geology 1969-1971: Alaska Div. of Geol. Survey, $94 \mathrm{p}$.

A convenfent source for general references to the Arctic which includes history, biology, etc. ag well as geology is the Arctic B1bllography:

Arctic Institute of North America, 1953- , Arctic blbliography: McGill-Queen's Univ. Press, v. 1- .

The complete bibliography of U.S. Geological Survey literature is included in the following:

U.S. Geological Survey, 1961, Publications of the Geological Survey 1879-196I, U.S. Geol. Survey, 457 p. , 1972, Publications of the Geologtcal Survey 1962-1970, U.S. Geol. Survey, 586 p.

- . . as weli as yeurly supplements and the monthly publication New Publications of the Geological Survey.

There is also a much shorter blbllography complled from the preceeding U.S. Geologlcal Survey sources which Includes only the Alaskan materlal and is updated periodically:

U.S. Geological Sluw:y, 1974, Ceologlc and watex-gupply reports and map5, AJaska: U.S. Geol. Survey, 68 p.

A bibliography of liferature of the Alaska Diviston of Geologlcal and Geophystcal Surveys 1 is included in each of thelr annual reports. They also furnish a list of their open-file reports upon request. 
Cobb has produced a series of open-file reports that tabulate vartous types of geologtc information from vartous agencies by 1:250,000 quadrangle:

Cobt, E. H., 1973, Index of metall1c mineral deposits of Alaska complied from reports in open fxles of the U.S. Geological Survey and U.S. Bureau of Mines: U.S. Geol. Survey open-file report, 87 .

Cobb, E. H., 1974, Geologlcal Survey open-flle reports on Alaska Indexed by quadrangle: U.S. Geol. Survey open-file report 74-7, $116 \mathrm{p}$.

Cobb, E. H., 1974, Reports of the Alaska Dlvision of Geological and Geophysical surveys and predecessor agencies, 1913-1973: U.S. Geol. Survey open-file report 74-209, $112 \mathrm{p}$.

Cobb, E. H., 1974, Selected U.S. Bureau of Mines reports on Alaska indexed by quadrangle: U.S. Geol. Survey open-file report $74-52,40 \mathrm{p}$.

Cobb. E. H., 1974, Ceological Survey published reports on Alaska, 1884-1914, indexed by quadrangle: U.S. Geol. Survey open-file report $74-345,126 \mathrm{p}$.

Cobb. E. H., 1974, Geologlcal Survey published reports on Alaska, 1915-1939, Indexed by quadrengle: U.S. Geol. Survey open-file report 74-335, $159 \mathrm{p}$.

Cobb, E. H., 1974, Geological Survey published reports on Alaska, 1940-1959, indexed by quadrangle: U.S. Geol. Survey open-file report $74-261,71$ p.

Cobb, E. H., 1974, Geologlcal Survey published reports on Alaska, 1960-1973, indexed by quadrangle: U.S. Geol. Survey open-file report $74-210,163 \mathrm{p}$.

Cobb, E. H., 1975, Geological Survey and selected U.S. Bureau of Mines and Alaska Division of Geological and Geophysical Surveys reports and maps on Alaska released during 1974 indexed by quadrangle: U.S. Geol. Survey open-file report $75-128,46 \mathrm{p}$.

So far as 18 known, there is no list of theses or dissertations based on Alaskan geological work. Neither is there a compilation of articles or notes of Alaskan mineral deposits or geology as found in newspapers and trade journals. 


\section{Keeping Current}

At least part of the problem in workting with Alaskan geology is the rapld accumulation of data and the diffrculty for the neophyte to the scene to determine who's doing what and where. The Alaska Dtviston of Geologtcal and Geophysical Surveys publishes an annual report of thetr work which includes information on work in progress or not yet published. In addition, their monthly newsletter, Mines and Geology Bulletin, provides timely news on geologic and mineral development throughout the year and deyotes a portion of a spring issue to a tabulation of the profects to be undertaken that sumer by Division personnel.

Each year in the late spring, the U.S. Geological Survey provides a sumary of the projects active during the previous year and those to be undertaken during the following sumer. Th1s is published as a Circular and 1ncludes in varying degree, the results of the previous sumbers work. The most recent of these C1reulars are:

U.S. Geological Survey, 1973, United States Geological Survey, Alaska Program 1973: U.S. Geol. Survey Clr. 683, 56 p.

Carter, Clalre (ed.), 1974, United States Ceological Survey Alaska Program, 1974: U.S. Geol. Survey CIr-700, 63 p.

Yount, M. E., (ed.), 1975, Unlted States Geological Survey Alaska Program, 1975: J.S. Geol. Survey C1r. 722, 58 p.

The U.S. Geologtial Survey also publighes a geries of annual reviews which sumarizes their work throughout the country. The most recent of these is:

U.S. Geological Survey, 1974, Geological Survey Research 1974; U.S. Geol. Survey Prof. Paper 900, 349 p. 
Th1s publication includes short sumuries of most of the geologic

work in Alaska; much of it is new information that has not been

published previously.

\section{Stratigraphic Nomenclature and \\ Radioactive Dates}

The basic bibliographic source for stratigraphlc nomenclature is

the U.S. Geological Survey lexicons:

Wilmarth, M. G., 1938, Lextcon of geologic names of the United States (including Alaska), 2 vols.: U.S. Geol. Survey Bull. 896,2396 p.

Keroher, G. C., and others, 1966, Lexicon of geologic names of the Untted Staces for 1936-1960: U.S. Geol. Survey Bull. 1200, $4341 \mathrm{p}$.

Keroher, G. C., 1970, Lexicon of geologic names of the United Srates, 1961-1967: U.S. Geol. Survey Bull. 1350, 848 p.

Levorsen has prepared an abbreviated list of stratigraphic names restricted to chose in use only in Alaska that may be more conventent for many purposes:

Levorsen, J. S., 1973, Alaska geologic lextcon reference data: Alaska Div. of Geol. and Geophys. Surveys, 26 p.

Radiometric dates (not including radiocarbon dates) through 1975

have been tabulated by quadrangle:

Turner, D. L., Grybeck, Donald, and Wilson, F. H., 1975, Radiometric dates from Alaska - a 1974 compilation: Alaska Div. of Geol. and Geophys. Surveys Special Reprot 10, $64 \mathrm{p}$.

The radioactive dates in this compliation have also been plotted on a set of $1: 1,000,000$ maps:

Turner, D. L., and Wilson, F. H., 1975, Radlometric age map of Alaska - Southeastern Alaska: Alaska Div. of Geol. and Geophys. Surveys open-E1le map AOF-82, $11 \mathrm{p}$. 
Turner, D. L., and Wilnon, F. H., 1975, Radtometrtc age map of Alaska - Aleutlan Islanda: Alaska DIF. of Geol. and Geophys. Surveys open-file map A.OR $-83,10 \mathrm{p}$.

Turner, D. L., and W1lson, P. H., 1975, Radlometric age map of Alaska - Southwestern Alaska: Alaska DIv. of Geol. and Geophys. Surveys open-f1le map AOF-84, $12 \mathrm{p}$.

Turner, D. L., and Wilson, F. H., 1975, Radiometric age map of Alaska - South-central Alaska: Alaska Div. of Geol. and Geophys. Surveys open-file map AOP-85, $12 \mathrm{p}$.

Turner, D. L., and Wilson, F. H., 1975, Radiometric age map of Alaska - Northern Alaska: Alaska Div, of Geol. and Geophys. Surveys open-file map AOF-86, $11 \mathrm{p}$.

\section{Metallic Mineral Deposits}

Information on Alaskan ore depostes is conveniently found in a variety of sources many of which overlap in thefr coverage. Some general sumaries are:

Berg, H. C., and Cobb, E, H., 1967, Metalliferous lode deposttg of Alaska: U.S. Geo1. Survey Bu11, 1246, 254 p.

U.S. Bureau of Mines, 1975, Alaska's energy and mineral potential: Alaska Fleld Operations Center, Juneau, Alaska, 7 p.

Clark, A. L., and others, 1974, Metal provinces of Alaska: U.S. Geol. Survey M1sc. Inv. Map I-834, 1 sheet, scale 1:5,000,000.

Cobb, E. H., 1973, Placer deposits of Alaska: U.S. Geol. Survey Bu11. 1374, $213 \mathrm{p}$.

Cosb, E. H., 1974, Synopsts of the mineral resources and geology of Alaska: U.S. Geol. Survey Bu11. 1307, 53 p.

Cobb, E. H., and Kachadoorian, Reuben, 1961, Index of metallic and non-metallic mineral deposits of Alaska from published reports of Federal and State agencies through 1959: U.5. Geol. Survey Bull. 1139, $363 \mathrm{p}$.

Cobb, E. H., 1974. Index of metallic mineral deposits of Alaska compiled from publlshed reports of Federal and State agencies through 1972: U.S. Geol. Survey, Nat. Tech. Information Service PB-233 217/AS, 590 p. 
Hawley, C, C., 1973, Minera1, helts and districts, prospective regions and land status in Alaska: The Mapmakers, Anchorage, $26 \mathrm{p}$.

Cobb and others have published a oet of $1: 250,000$ maps of Alaska that show the locality, comodity or comodities of interest, lode or placer, and production or lack of it Eor every known metallic mineral deposte in Alaska. TAls extremely useful compllation is published in the Miscellaneous FIeld Studieg (MP) series of the U.S. Geological Survey. Rather than clte each individually, Figure 1 on the next page Indicates the number of the apprortate MF map for each quadrangle.

A new serfes of open-flle reports has been initiated by Cobb that bullds on the preceeding sertes of maps. Every metallic mineral occurrence In the quadrangle 18 discussed systematically with a short gurmary or excerpt for each citation pertinent to that occurrence in the reports of the Geologlcal Survey, the U.S. Bureau of Mines, and the Alaska Div151on of Geological and Geophystcal Surveyg as well as a short overall sumary for each occurrence. The first publicacions of this serles are:

Cobb, E. H., 1975, Sumary of references to mineral occurrences (other than minexal fuels and construction materlals) in the Bendeleben quadrangle, Alaska: U.S. Geol. Survey open flle report $75-429,120 \mathrm{p}$.

Cobb, E. H., 1975, Summary of references to mineral occurrences (other than mineral fuels and construction materials) in the Teller quadrangle, Alaska: U.S. Geol. Survey open-file report $75-587,142 \mathrm{p}$.

Cobb, E. H., 1975, Summary of references to mineral occurrences (other than mineral Euels and congtruction materlals) In five quadrangles In west-central Alaska (Hughes, Kotzebue, Melozitna, Selawik, Shungnak): U.S. Geol. Survey open-file report 75-726, $58 \mathrm{p}$. 


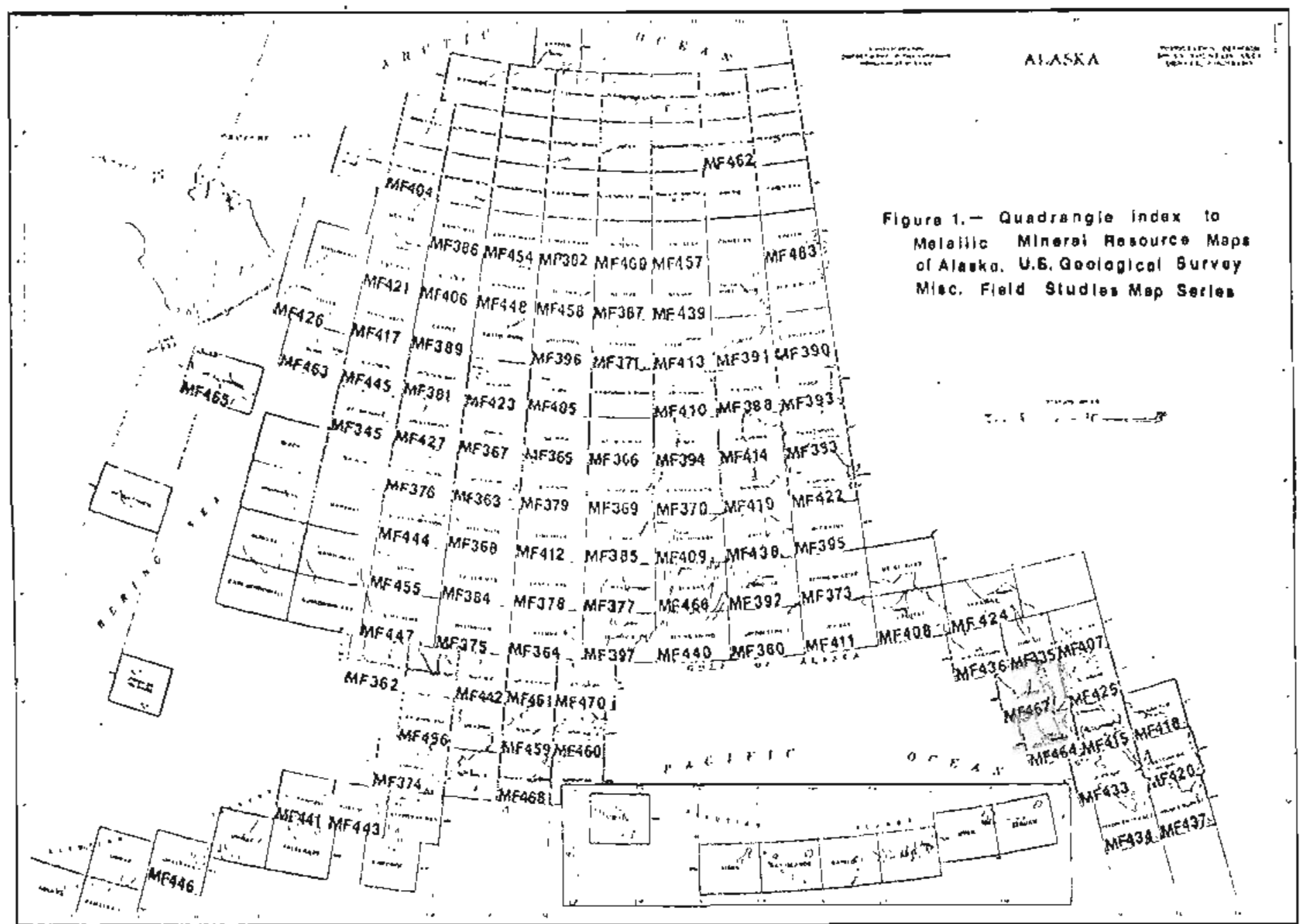


Cobb, E. H., 1975, Summary of references to mineral occurrences (other than mineral fuels and construction materlals) in northern Alaska: U.S. Geol. Survey open-file report $75-628,106$ p.

Cobb has also presented a serles of maps by comodity that shows every known occurrence of that comodity in the state:

Cobb, E. H., 1962, Lode gold and sllver occurrences in Alaska: U.5. Geol. Survey, Mineral Inv. Resources Map, MR-32, 1 sheet, scale $1: 2,500,000$.

Cobb, E. H., 1964, Iron occurrences in Alaska: U.S. Geol. Survey Mineral Inv. Resources Map MR-40, I sheet, scale 1:2,500,000.

Cobb, E. H., 1964, Industrial minerals and construction materials occurrences in Alaska: U.5. Geol. Survey Mineral Inv. Resources Map MR-41, 1 sheet, scale 1:2,500,000.

Cobb, E. H., 1970, Antimony occurrences tn Alaska: U.S. Geol. Survey Mineral Inv, Resources Map MR-52, 4 p.

Cobb, E. H., 1970, Bismuth occurrences in Alaska: U.S. Geol. Survey Mineral Inv. Resources Map MR-53, 2 p.

Cobb, E. H., 1970, Mercury occurrences 1n Alaska: U.S. Geol. Survey Mineral Inv. Resources Map MR-54, 2 p.

Cobb, E. H., 1970, Uranium, thorium and rare-earth elements in Alaska: U.S. Geol. Survey Mineral Inv. Resources Map MR-56, 3 p.

Cobb, E. H., 1974, Molybdenum occurrences in Alaska: U.S. Geol. Survey Mineral Inv. Resources Map MR-59, 3 P.

Cobb, E. B., 1974, Cobalt occurrences in Alaska: U.S. Geol. Survey Mineral Inv. Resources Map MR-61, 1 p.

Cobb, E. H., 1974, Copper occurrences in Alaska: U.S. Geol. Survey Mineral Inv. Resources Map MR-62, $18 \mathrm{p}$.

Cobb, E. H., 1974, Nickel occurrences in Alaska: U.S. Geol. Survey Mineral Inv. Resources Map MR-63, $2 \mathrm{p}$,

Cobb, E. H., 1975, Occurrences of platinum-group metals in Alaska: U.S. Geo1. Survey Mineral Resources Map MR-64, 2 p.

Cobb, E. B., 1974, Tin occurrences tn Alaska: U.S. Geol.

Survey Mineral Inv. Resources Map MR-65, $4 \mathrm{p}$. 
Cobb, E. H., 1975, Tungsten occurrences in Alaska: U.S. Geol. Survey Mineral Inv. Resources Map MR-66, 5 p.

Cobb, E. H., 1975, Zinc occurrences in Alaska: U.S. Geol. Survey Mineral Inv. Resources Map MR-67, 9 p.

Cobb, E. H., 1975, Chromite occurrences in Alaska: U.S. Geol. Survey MIneral Inv. Resources Map MR-68, 2 p.

Cobb, E. H., 1975, Lead occurrences 1n Alaska: U.S. Geol. Survey MIneral Inv. Resources Map MR-69, $12 \mathrm{p}$.

The Mineral Industry Research Laboratory of the University of Alaska has summarized the metallic mineral deposits of a number of large areas of the state. These publications have an introductory gectlon which includes a summary of the geology of the area and a computerized tabulatton of all known mineral deposits in the state based on both published sources and clatm location:

Heiner, L. E., and Wolff, E. N., 1968, Mineral resources of Northern Alaska: Mineral Industry Research Lab., Univ, of Alaska, Report 16, $306 \mathrm{p}$.

Lu, F. C. J., Heiner, L. E., and Harris, D. P., 1968, Known and potential ore reserves, Seward Peninsula, Alaska: Mineral Industry Research Lab., Untv, of Alaska, Report 18, $105 \mathrm{p}$.

Heiner, L. E., Wolff, E. N., and Grybeck, Donald, 1971, Copper mineral occurrences in the Wrangell Mountain-Prince Wilizam Sound area, Alaska: Mineral Industry Research Lab., Univ. of Alaska, Report 27, 179 p.

Wolff, E. N., and heiner, L. E., 1971, Mineral resources of Southeastern Alaska: Mineral Industry Research Lab., Untv. of Alaska, Report 28, $334 \mathrm{p}$.

The reglonal studies are complemented by a computer tabulation of every known mine, prospect, and claim in Alaska - the Minfile. This tabulation does not include a rextual description of the geology of the deposits but there Is an extended discussion of the computer program. The tapes of the data are also avallable through M.I.R.L. 
Helner, L. E., and Porter, Eve, 1972, A computer processable storage and retrleval program for Alaska mineral informat1on, 2 vols.: Mineral Industry Research Lab., Untv, of Alaska, Report 24, 814 p.

It might be conventent if there was some comprehenslve source for Information on the data collected or even the localitles worked by private Industry. Understandably, they are reticent to make this Information available, but some 1nformation is of ten avallable through their staking activity. Records on mineral claims are conveniently evallable in the Kardex files maintained by the Alaska Division of Geological and Geophysical. Surveys in Fairbanks. The material is Indexed by quadrangle with an individual entry for every claim that has been recorded in the state of Alaske. The entry includes present and past ownership, location, history of activity, the status of assessment work, and the commodtty of 1nterest. The file can be examined in 1ts entirecy only at Falrbanks but all materlal in it can be photocopled at $\cos t$

$$
\text { 011, Gas and CoBl }
$$

The Information on Alaska's ofl, gas and coal resources are spread through a variety of sources, many of which have already been cited. The following are especially useful in addition to those mentloned previously:

Barnes, F. F., 1967, Coal resources of Alaska: U.S. Geol. Survey Bul1. 1242-B, P. B1-B36.

Carter, R. D., Denman, J. M., and Plerpoint, J. G., 1975, Geologlcal literature on the North Slope of Alaska, 1969-1974: U.S. Geol. Survey open-file report $75-384,81 \mathrm{p}$. 
Xlein, R. L., and others, 1974, Energy and mineral resources of Alaska and the impact of federal land pollcies on thetr avallabll1ty-o1l and gas: Alaska Div. of Geol. and Geophys. Surveys open-file report AOF-50, $18 \mathrm{p}$.

Lyle, W. M., and Bragg, N. J., 1974, Coal blbllography for Alagka: Alaska Div. of Geol. and Geophys. Surveys open-file report $\mathrm{AOF}-41,31 \mathrm{P}$.

Maher, J. C., and Troliman, W. M., 1970, Geologic literature on the North Slope of Alaska: Amer. Assoc. Petroleum Geologists, $133 \mathrm{p}$.

McGee, D. L., and $0^{\prime}$ Connor, K. M., 1975, Mineral resources of Alaska and the impact of federal land pollcies on their avallability-coal: Alaska Div. of Geol. and Geophys. Surveys open-file report AOP $-51,29 \mathrm{p}$.

Miller, K. J., Payne, T. G., and Gryc, George, 1959, Geology of possible petroleum provinces in Alaska: U.S. Geol. Survey Bu1l. 1094, $131 \mathrm{p}$.

Petroleum Publications Inc., Anchorage, is the commercial outlet for well logs in Alaska as well as a variety of other information related to Alaskan mineral development. For 1nstance, they serve as the source for the Alaska Division of Geological and Geophysical Surveys open-file reports and they publish The Alaskan Scouting Service, a weekly sumary of ofl, gas and mineral developments in the state.

We11 logs and well cuttings of all wells upon which information has been released to the public are also avallable for examination at the Anchorage offices of the Alaska Division of Geological and Geophysica1 Surveys.

\section{Aertal Photography and} Space Imagery

Aerlal photography is avallable for almost all of the state although tt is held by a number of federal agencles and commerctal 
outlets. The format of the photography varles and there may be some delay in obtalning the material.

Two different approaches way be used to determine the avatlab1lity and ordering information for photography of any given area. The first involves talking with a topographlc englneer that has personal knowledge of Alagkan aerlal photography and access to the photoindices. The U.S. Geological Survey headquarters a topographlc engineer at 218 " $E$ " Street, Anchorage, Alaska and several at the Federal Center, Denver, Colorado. For many geologic purposes, the U.S. Geologlcal Survey phorography is sufficient and one need only examine the fadex produced by the 30th Engtneer Group of the U.S. Army to select the needed photographs. This index can be examined in Aachorage at the address given above and at the offices of the U.S. Geological Survey, O'Neill Bldg., Unlverstty of Alaska, Falrbanks, Alaska 99701.

The other approach is to contact the EROS Daca Cencer, Sloux Falls, South Dakota, 57198. They will eventually hold the negetives of a11 U.S. Geological Survey aerial photography and have access through a federal computer network to all aerial photography flown in Alaska. As an aid to an evaluation of your needs, they have prepared a form Geographic Computer Search, which they will use to furnish a list of the photography that w11l fit user needs.

Simllarily satellite data which are malnly from the LANDSAT (previously known as ERTS) satellite is avallable for almost all of the state. Three offlces that have Ind1ces of all the available 1magery as well as personnel avallable to discuss user needs and a comprehensive 
collection of the actual products are:

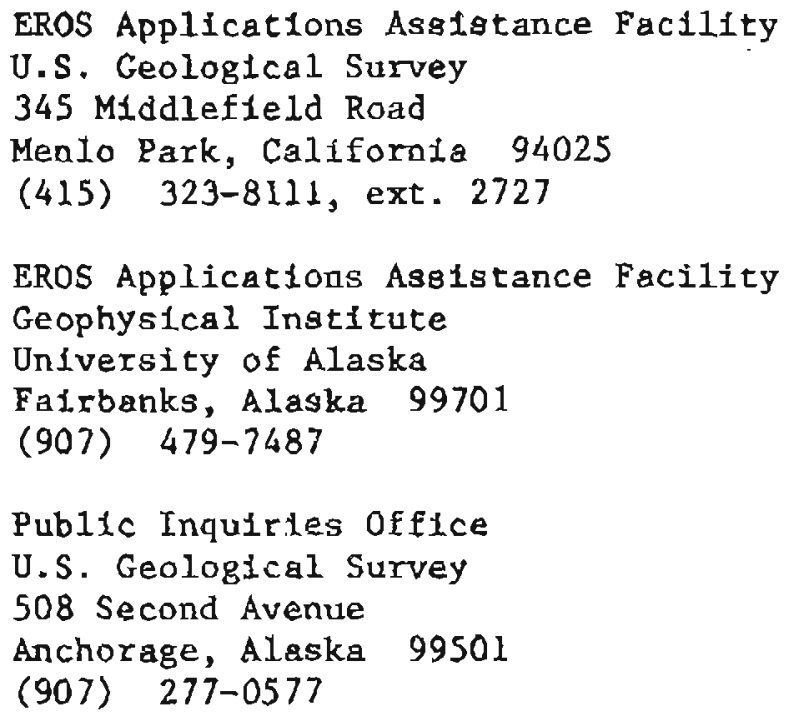

The EROS Data Center In Sioux Falls, South Dakota, 57198, can also be contacted for remote sensing lmagery in the same manner as for aerial photography.

Location of Pubiications and Sourceg of Information

Two distanct types of sources for Alaskan geologic Lnformation are usefully distinguished, Larger libraries undoubtedly offer the most direct access to the publications themselves. However, while they are conventently catalogued and the librarles offer a wide range of matertal and services, they almost invariably lack professional geologlcal staff. In contrast, the various state and Federal agencles often have professional staff avallable in thelr offices for assfotance. Their library facilitles are often limfed, however, and the materlal is usually nor catalogued. Professional staff members can frequently answer an esoteric quegtion lmmediately from thetr own knowledge or 
refer the questioner to one who can. They are, however, constrained by their other duties and generally must resort to referral to library sources for general questions that demand extensive literature research. Two llbrarles in Alaska have most of the publications cited as well as a comprehensive collection of geologic literature. They are:

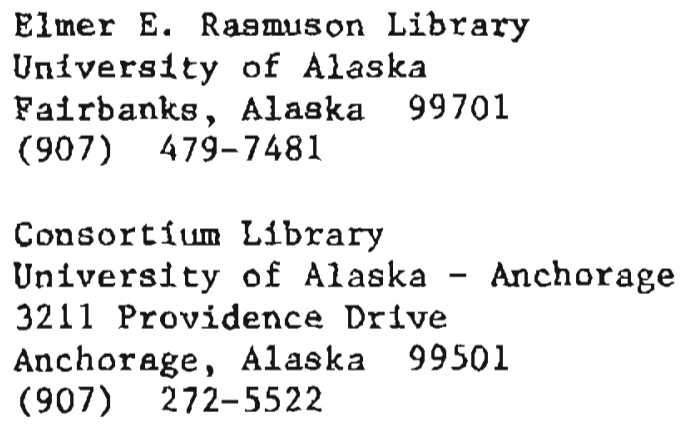

The U.S. Geological Survey maintains a Public Inquiries Office In Anchorage that is speciflcally orlented toward answering questions from the public. It has a complete file of U.S.G.S. publications on Alaska and many of the others as well; it also acts as a sales agency for U.S. Geologlca1 Survey book publications and maps:

Public Inquiries office

U.S. Geological Survey

508 West 2nd Avenue

Anchorage, Alaska 99501

(907) 277-0577

The Geologic Division of the U.S. Geological Survey malntains two offlces in Alaska for their professional personnel:

Branch of Alaskan Geology

U.S. Geologtcal Survey

1209 Orca Street

Anchorage, Alaska 99501

(907) 272-8228 or (907) 274-2133 


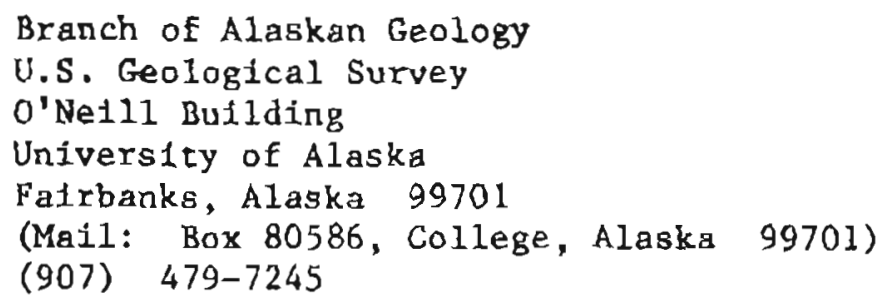

The headquarters of the Branch of Alaskan Geology is at the Western Reglon Center of the U.S.G.S. at Menlo Park, Califronia:

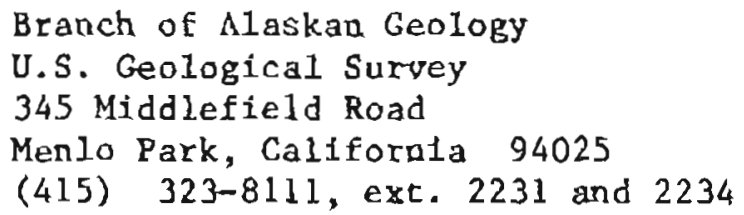

Most of the professlonal staff of the Alaskan Branch can be reached there. The Branch also maintafns a comprehensive library of Alaskan geologlc 1iterature in their Technical Data Uait (T.D.U.) at Menlo Park, Califorata, (415) 323-8111, ext, 2342.

The Conservation Division and the Water Resources Diviston of the U.S. Geological Survey have offices in Alaska which handle much of their work in the state:

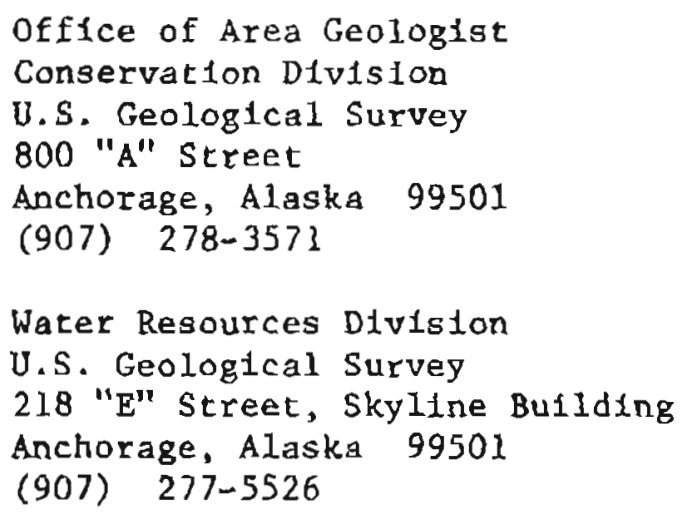

The Alaska Division of Geological and Geophysical Surveys maintains two offices in Alaska that are devoted primartly to geologtc work: 
Diviston of Geological and Geophyslcal Surveys (P.0. Box 80007)

o'Nelll Building

Untverstty of Alaska

Falrbanks, Alaska 99701

(907) $\quad 479-7062$

Division of Geological and Geophysical Surveys 3001 Porcupine Drive

Anchorage, Alaska 99501

(907) 274-8062

The matn center for U.S. Bureau of Mines work in Alaska is in

Juneau; there are smaller offices in Fairbanks and Anchorage:

Alaska Field Operations Center

U.S. Bureau of Mines

P.O. Box 550

Juneau, Alaska 99801

(907) 364-2111

U.S. Bureau of Mines

o'Nelll Butlding

Universicy of Alaska

Falrbanks, Alaska 99701

(907) 479-6807

U.S. Bureau of Mines

(P.0. Box 2059)

605 West 4th Ayenue

Aachorage, Alaska 99501

(907) 265-5206 